\title{
STRATEGI PEMBANGUNAN KETAHANAN DAN KETERSEDIAAN \\ PANGAN TINGKAT LOKAL NUSA TENGGARA TIMUR DI TENGAH PERUBAHAN IKLIM MELALUI PENDIDIKAN DI SMK-PP NEGERI KUPANG
}

\author{
Wahyu Hadi Trigutomo \\ Universitas Negeri Malang \\ muhammadsofi8483@gmail.com
}

\begin{abstract}
Nowadays, the availability of national food cannot accommodate all the food needs of nation's people, especially in each region. This current issue is caused by the absence of an effective arrangement, the absence of synchronization among state institutions, especially among the agricultural, trade and housing agencies, and the presence of an extreme climate change currently. In addition, the issues of the regeneration of farmers that have not shown any continuity that had been cut off among the younger generations led to the changes in the pattern of community life in the region. Therefore, based on the aforesaid issues, this paper aims at finding out on how the strategy and policy of food development in the local food availability in the midst of climate change today can be overcome by changing the mindset of consumptive to productive young generation through agricultural education, utilization of empty land which is available for planting food crops, empowerment of farmer groups, socialization of the local food potentials in East Nusa Tenggara. As a result, the food security can be realized and the region cannot be dependent its food needs on the other regions. Therefore, the writer attempts to formulate the strategy of food security developments from education aspects through the Dick \& Carey development strategy. Food is an important and strategic commodity for the region because food is the basic human need that must be provided collectively by the government and society as mandated by the Acts No. 7 of 1996 on food. With respect to the Acts No. 7 of 1996 on food, it is stated that the Government organizes the regulation, guidance, control and supervision of the community, and organizes the process of production and supply, trade, distribution and in the same time, the Government also serves as a consumer that is entitled to adequate food, in terms of quantity and quality, safety, nutrition, variety, equity, and affordability by all society. The availability of national food can be fully fulfilled if it is commenced from the food sufficiency in the levels of family. In regard to the local area, it is marked by the existence of food consumption which can fulfill the sufficiency of every individual, in terms of balanced nutrition. In fact, it then has an impact on sufficiency of food and the nutrition status of Indonesian society can be fulfilled locally, especially in East Nusa Tenggara. The availability of food in terms of adequate quantities and types for the whole community locally in East Nusa Tenggara, smooth food distribution, cheap food prices and affordability by the all levels of society locally in East Nusa Tenggara, evenly distributed to all families in the region.
\end{abstract}

Keywords: development strategy, national food security, local food, climate changes.

ABSTRAK
Ketersediaan bahan pangan nasional dewasa ini belum bisa mengakomodir semua
kebutuhan pangan warga negaranya khususunya di masing - masing daerah, hal ini
disebabkan belum adanya penataan yang efektif serta tidak adanya sinkronisasi antar
lembaga negara, terutama antara instansi pertanian, perdagangan dan perumahan serta
adanya perubahan iklim yang cukup ekstrim dewasa ini. Selain hal tersebut, permasalahan
regenerasi petani yang mulai terputus di generasi muda menyebabkan terjadi perubahan
pola hidup masyarakat di daerah. Melihat permasalahan di atas tujuan tulisan ini untuk
mengetahui bagaimana strategi dan kebijakan pembangunan pangan dalam ketersediaan
pangan lokal di tengah perubahan iklim dewasa ini dapat disiasati dengan perubahan pola
pikir konsumtif ke produktif generasi muda melalui pendidikan pertanian,


mendayagunakan lahan kosong yang ada untuk ditanami tanaman pangan, memberdayakan kelompok tani, mensosialisasikan potensi pangan lokal NTT, sehingga dapat terwujud ketahanan pangan dan tidak ketergantungan pada pangan pokok daerah lain. Untuk itu penulis berusaha menyusun strategi pembangunan ketahanan pangan dari aspek pendidikan melalui strategi pengembangan Dick \& Carey. Pangan merupakan komoditas penting dan strategis bagi bangsa daerah mengingat pangan adalah kebutuhan dasar manusia yang harus dipenuhi oleh pemerintah dan masyarakat secara bersama-sama seperti diamanatkan oleh Undang Undang Nomor 7 tahun 1996 tentang pangan. Dalam Undang Undang Nomor 7 tahun 1996 tentang pangan dinyatakan bahwa Pemerintah menyelenggarakan pengaturan, pembinaan, pengendalian dan pengawasan masyarakat, menyelenggarakan proses produksi dan penyediaan,perdagangan, distribusi serta berperan sebagai konsumen yang berhak memperoleh pangan yang cukup dalam jumlah dan mutu, aman, bergizi, beragam, merata, dan terjangkau oleh daya beli masyarakat.Ketersediaan bahan pangan nasional dapat tercukupi bila dimulai dari ketercukupan pangan tingkat keluarga, lokal daerah ditandai dengan adanya konsumsi pangan setiap individu terpenuhi kecukupan gizi seimbang dapat menikmati yang berdampak pada kecukupan pangan dengan baik dan status gizi masyarakat Indonesia terpenuhi secara lokal NTT.ketersediaan pangan dalam jumlah dan jenis yang cukup untuk seluruh masyarakat secara lokal NTT, distribusi pangan yang lancar, harga pangan murah dan terjangkau oleh lapisan masyarakat secara lokal NTT, merata keseluruh keluarga di daerah.

Kata kunci: strategi pembangunan, ketahanan pangan nasional, pangan lokal, perubahan musim.

\section{PENDAHULUAN}

Problematika dalam dunia pertanian dalam usaha mencukupi dan membangun ketahanan pangan di tingkat nasional sampai sekarang belum bisa secara penuh dapat di selesaikan, ditambah dengan adanya perubahan iklim yang terjadi dewasa ini. Adapun masalah yang dihadapi pemerintah propinsi Nusa Tenggara Timur dalam bidang peningkatan ketahanan pangan di bidang pertanian di tengah perubahan iklim yang ektrim adalah sebagai berikut:

a. Belum maksimalnya pengoptimalan luas lahan tanaman pangan lokal;

b. Meningkatkan laju pertumbuhan ekonomi,;

c. Pengurangan Kemiskinan;

d. Peningkatan kualitas Sumber Daya Manusia;

e. Peningkatan derajat kesehatan penduduk.

Permasalahan tersebut sangat diperlukan pemecahan yang mendesak ditengah kondisi masyarakat yang dinamis dan membutuhkan pemenuhan kebutuhan pokok mereka, terutama kebutuhan pemenuhan ketahanan pangan keluarga.Hal tersebut dapat di selesaikan melalui peningkatan kualitas Sumber Daya Manusia melalui pendidikan, khususnya yang bergerak di bidang pertanian yaitu di SMKPP Negeri Kupang. Ketahanan pangan diartikan sebagai terpenuhinya pangan dengan ketersediaan untuk kebutuhan masyarakat secara keluarga, lokal dan nasional, tersedia, mudah memperoleh, aman dikonsumsi dan harga terjangkau oleh lapisan masyarakat umum, yang dapat diwujudkan dengan bekerjanya sub sistem ketersediaan, sub sistem distribusi, dan sub sistem konsumsi.

Sebagai lembaga pendidikan di bidang pertanian, SMK-PP Negeri Kupang mempunyai andil besar dalam mengatasi problematika pertanian dengan dihasilkannya tenaga-tenaga terampil dan ahli serta kreatif di bidang pertanian khususnya pangan. Provinsi Nusa Tenggara Timur (NTT) merupakan provinsi yang sering mengalami berbagai masalah yang berkaitan dengan ketahanan pangan seperti kelangkaan pangan,gagal panen, dan busung lapar.

Tujuan artikel ini adalah untuk memperoleh langkah dan strategi pembangunan ketahanan pangan di tingkat lokal Nusa Tenggara Timur untuk menunjang ketahanan pangan nasional. 
Dalam memahami strategi pembangunan ketahanan pangan nasional melalui ketersediaan pangan lokal bisa menggunakan model yang dikembangkan oleh Dick, Carey and Carey , 2001)yang memuat sepuluh langkah yaitu:

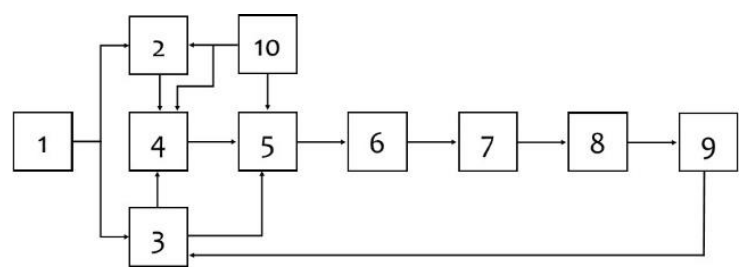

Gambar 1. Alur langkah Dick \& Carey untuk meningkatkan ketahanan pangan lokal

Keterangan:

1. Menilai kebutuhan untuk mengidentifikasi tujuan umum pembangunan pertanian;

2. Melakukan analisis tujuan umum pembangunan pertanian;

3. Menganalisis kondisi alam dan lingkungan;

4. Menulis tujuan khusus pembangunan pertanian;

5. Mengembangkan Instrumen Penilaian;

6. Mengembangkan strategi pembangunan pertanian;

7. Mengembangkan materi pembangunan pertanian;

8. Merancang dan melakukan evaluasi formatif;

9. Merevisi Pembangunan pertanian;

10. Merancang dan melaksanakan evaluasi sumatif.

Beberapa tantangan yang dihadapi oleh pemerintah propinsi Nusa Tenggara Timur untuk mencukupi dan membangun ketahanan pangan di tingkat lokal Nusa Tenggara Timur yang membutuhkan strategi pembangunan ketahanan lokal adalah sebagai berikut:

a. Belum maksimalnya pengoptimalan luas lahan tanaman pangan lokal yang mencapai 210.000 ha yang baru mencapai $45 \%$ saja.

b. Meningkatkan laju pertumbuhan ekonomi dan meningkatkan landasan ekonomi daerah yang memperluas kesempatan kerja dan mempercepat peningkatan kesejahteraan ekonomi masyarakat Pada tahun 2010 rasio antara PDRB perkapita NTT dan PDB nasional sebesar 32,37 persen, maka pada tahun 2014 rasionya sedikit menurun menjadi 32,10 persen. Sumber: BPS, 2014

c. Pengurangan Kemiskinan; Tingkat kemiskinan NTT pada tahun cenderung menurun namun berada di atas rata-rata nasional. Selama kurun waktu 20102014 kemiskinan di NTT berkurang sebesar 3,03 persen. Persentase penduduk miskin di NTT tergolong tinggi, pada tahun 2014 persentase penduduk miskin di nasional mencapai 10,96 persen, sedangkan di NTT sebesar 19,8 persen. Kemiskinan dipengaruhi oleh sikap dan kebiasaan hidup yang tidak produktif, rendahnya tingkat pendidikan dan derajat kesehatan, di samping terbatasnya lapangan kerja serta terbatasnya dukungan sistem kelembagaan sosial dan ekonomi. Sumber: BPS, 2014

d. Peningkatan kualitas Sumber Daya Manusia melalui pendidikan, Indikator yang menentukan kualitas pendidikan adalah tingkat pendidikan tertinggi yang ditamatkan. Pada tahun 2014, persentase penduduk usia 10 tahun ke atas di NTT yang berpendidikan minimal SD sebesar 34,43 persen, sedangkan penduduk yang tamat sampai jenjang perguruan tinggi hanya 5,3 persen (BPS Provinsi NTT, 2015). Ini menunjukkan kualitas dan daya saing sumber daya manusia di NTT belum memadai, karena semakin banyak penduduk berpendidikan rendah semakin tertutup akses untuk mendapat pekerjaan dan pendapatan yang lebih baik.

Hal ini menyebabkan SDM tidak mampu menjawab berbagai kebutuhan dan daya saing yang terjadi pada lingkup regional, nasional, maupun internasional. Provinsi NTT perlu konsisten dalam meningkatkan APS (Angka Partisipasi Sekolah), AMH (Angka Melek Huruf), dan RLS (Rata-rata Lulusan Sekolah), sehingga penyelenggaraan layanan untuk pemerataan 
akses dan mutu pendidikan dapat tercapai. Salah satu hal yang tidak kalah pentingnya adalah perlunya dilakukan analisis terhadap kondisi umum pendidikan, prioritas bidang, prioritas wilayah dan anggaran sebagai suatu kesatuan analisis pemecahan masalah penyelenggaraan pembangunan pendidikan di NTT. Sumber: BPS, 2014

\section{Peningkatan derajat kesehatan penduduk}

Kesehatan merupakan salah satu aspek kesejahteraan dan fokus utama pembangunan manusia, karena kesehatan sebagai modal berharga bagi seseorang dalam melakukan aktifitas kehidupannya. Untuk meningkatkan derajat kesehatan penduduknya, Pemerintah melakukan berbagai program seperti memberikan kemudahan pelayanan kesehatan dengan penambahan tempat pelayanan kesehatan dan tenaga medis. Adapun sasaran utama pembangunan kesehatan adalah meningkatkan Angka Harapan Hidup (AHH), menurunkan Angka Kematian Bayi (AKB), Angka Kematian Ibu (AKI) serta prevalensi gizi buruk dan gizi kurang. Tingkat kesehatan masyarakat NTT belum menunjukkan hasil yang baik apabila dilihat dari indikator kesehatan, seperti angka kematian ibu, angka kematian bayi dan balita, serta gizi buruk yang berada di atas nasional. Tingginya angka kematian bayi dan ibu hamil di NTT disebabkan kurangnya tenaga kesehatan terutama di daerah terpencil.

Rendahnya aksesibilitas antarpulau, tingginya disparitas antarwilayah, serta persebaran penduduk yang tidak merata, membuat pelayanan kesehatan dengan tenaga yang minim menjadi tidak maksimal dan tidak merata kepada masyarakat. Peningkatan derajat dan status kesehatan penduduk tidak terlepas dari pengaruh ketersediaan dan keterjangkauan tenaga kesehatan. Indikator yang dapat digunakan untuk melihat ketersediaan tenaga kesehatan digunakan rasio dokter; bidan/perawat; dan tenaga kesehatan lainnya.

Ketersediaan tenaga kesehatan di NTT masih terbatas dan tidak terdistribusi merata. Jumlah ketersediaan tenaga kesehatan di NTT pada tahun 2014 masih rendah jika dibandingkan jumlah penduduk NTT, yaitu sebesar 1:472 (1 tenaga kesehatan harus melayani 472 orang penduduk). Angka kematian bayi di NTT pada tahun 2012 sebanyak 45 kematian per 1000 kelahiran baru, sedangkan angka nasional menunjukkan 34 kematian per 1000 kelahiran baru. Angka ini mengalami penurunan bila dibandingkan dengan kondisi pada 2007, angka kematian bayi NTT 57 kematian per 1000 kelahiran hidup.

Sementara itu, angka kematian balita mencapai 58 kematian per 1000 kelahiran hidup atau turun dari kondisi tahun 2007 sebesar 86 kematian per 1000 kelahiran hidup. Sumber: BPS, 2014

\section{Masalah ketahanan pangan}

Untuk merealisasikan program pemerintah mengenai ketahanan pangan di NTT masyarakat didorong untuk meningkatkan pencapaian produksi bahan pangan seperti padi, jagung, maupun kedelai. Padi merupakan bahan makanan utama di NTT.

Produksi padi di Provinsi NTT cenderung meningkat selama $2011-2015$. Pada tahun 2014 produksi padi mengalami penurunan sebesar 3,51 persen atau 77.061 ton. Hal ini sejalan dengan penurunan luas panen padi yaitu sebesar 0,99 persen atau 4.345 ha. Selama sepuluh tahun terakhir produksi padi di NTT cenderung meningkat 4,95 persen per tahun. Hal ini disebabkan karena meningkatnya produktivitas sebesar 1,31 persen dan luas panen 3,43 persen. luas panen padi pada musim tanam tahun ini meningkat sebesar 8,97 persen dan produktivitas juga meningkat hingga 4,80 persen.

Untuk memenuhi target panen padi NTT telah memiliki sejumlah sentra produksi padi. Secara akumulatif target tersebut dapat dicapai dengan memanfaatkan lahan seluar 126.000 hektar yang tersebar di seluruh kabupaten dan kota. Di Kabupaten Manggarai panen padi mencapai 9,6 ton/hektar pada tahun 2015 . Pemerintah juga mengupayakan pembangunan infrastruktur dan perbaikan 
di bidang pengairan, seperti irigasi terseier, waduk, dan bendungan. Bantuan peralatan pertanian seperti mesin giling, mesin perontok, traktor, dan pompa air juga diperlukan untuk meningkatkan produksi dan produktivitas padi.

Peningkatan produksi jagung dan kedelai juga menjadi prioritas pemerintah Provinsi NTT. Produksi dan produktivitas jagung di Provinsi NTT selama tahun 20112015 berfluktuatif dan mencapai produksi tertinggi pada tahun 2012, yaitu sebesar 707.642 ton. Pada tahun 2014 dan tahun 2015 produksi dan produktivitas jagung kembali meningkat namun peningkatannya belum sebesar produksi pada tahun 2012 . Produksi jagung tahun 2015 sebanyak 690.710 ton pipilan kering, mengalami kenaikan sebesar 43.602 ton $(6,74$ persen) jika dibanding tahun 2014 sebesar 647.108 ton pipilan. Jagung merupakan produksi andalan di NTT, kenaikan produksi pada tahun 2015 terjadi karena produktivitas dan luas panen meningkat.

Untuk komoditas kedelai, kontribusi produksi kedelai di NTT tidak sebesar jagung dan padi. Produksi kedelai tahun 2015 sebanyak 2.713 ton biji kering meningkat sebanyak 3 ton $(0,01$ persen $)$ dibanding tahun 2014 sebanyak 2.710 ton biji kering. Naiknya produksi kedelai disebabkan bertambahnya luas panen dan meningkatnya produktivitas. Daerah yang potensial untuk pengembangan kedelai di NTT adalah di Pulau Flores. Kendala yang dihadapi pada pengembangan kedelai adalah tingkat curah hujan yang rendah serta kemampuan tanah dalam menyerap dan menyimpan air. Agar mencapai produkstivitas tinggi petani perlu memperhatikan pengolahan tanah, pola tanam, dan manajemen organisme pengganggu tanaman. Sumber: BPS, 2014

\section{HASIL DAN PEMBAHASAN}

\section{Kebijakan Peningkatan Produksi Tanaman Pangan Lokal}

Upaya untuk menghindari kerawanan pangan yang dialami oleh daerah-daerah yang memiliki kondisi alam dan curah hujan yang relatif sedikit seperti provinsi NTT, maka diperlukan suatu kebijakan yang sesuai dengan kondisi alam sehingga implementasinya lebih mudah. Menurut Pakpahan dan Pasandaran (1990: 68) ketahanan pangan merupakan resultan dari interaksi antara teknologi, sumberdaya alam, modal, dan sumberdaya manusia yang dikoordinasikan baik melalui mekanisme pasar ataupun mekanisme pengaturan lainnya seperti kebijakan pemerintah yang mengatur program produksi pertanian. Dipandang dari segi ini, permasalahan dan tantangan utama untuk mencapai derajat ketahanan pangan yang lebih tinggi adalah permasalahan dalam pengorganisasian seluruh subsistem dalam sistem pangan yaitu pengorganisasian: 1) subsistem masukan, 2) subsistem produksi, 3) subsistem pemasaran, dan 4) subsistem konsumsi.

Selain

memperhatikan pengorganisasian, permasalahan ketahanan pangan perlu dibedakan pada berbagai situasi

seperti:

a. Permasalahan utama ketahanan pangan di mana jumlah pangan yang tersedia tidak mencukupi kebutuhan pangan penduduk. b. Permasalahan ketahanan pangan pada situasi di mana jumlah pangan yang tersedia secara statistik agregat mencukupi kebutuhan pangan penduduk, tetapi distribusinya kurang baik.

c. Permasalahan ketahanan pangan pada situasi di mana jumlah pangan yang tersedia secara statistik agregat mencukupi kebutuhan pangan penduduk, tetapi sebagian kelompok masyarakat tidak dapat memperoleh bahan pangan karena mereka tidak memiliki daya beli yang cukup.

Masalah ketahanan pangan pada situasi di mana jumlah pangan yang tersedia secara statistik agregat tidak mencukupi kebutuhan pangan penduduk dan masyarakat tidak memperoleh bahan pangan karena daya beli rendah, serta persoalan distribusi menuntut upaya keras dalam meningkatkan produksi pangan lokal, peningkatan pendapatan petani, dan memperbaiki sarana dan prasarana serta kelembagaan. Hal inilah yang kemudian memicu pemerintah provinsi Nusa Tenggara Timur mengeluarkan berbagai 
kebijakan dalam rangka menuntaskan permasalahan kerawanan pangan tersebut.

Kebijakan peningkatan produksi pangan lokal di provinsi Nusa Tenggara Timur telah dilaksanakan yang bertujuan meningkatkan pendapatan petani pedesaan di NTT. Sejak dahulu para gubernur ketika memulai masa jabatannya, yang pertama kali dicanangkan adalah kebijakan stategis yang membantu petani agar dapat meningkatkan produksi pertanian dan pendapatannya. Di antara program tersebut adalah Program Operasi Nusa Makmur (ONM), Program Operasi Nusa Hijau (ONH), Program Meningkatkan Pendapatan Asli Rakyat (Gempar), Program Membanguan Desa (Gerbades), Program Tiga Batu Tungku, yang memadukan tiga program prioritas yakni ekonomi, kesehatan, dan pendidikan. Pangan terakhir adalah program Anggur Merah yang merupakan singkatan dari anggaran pembangunan untuk mensejahterakan rakyat.

Di antara kebijakan operasional peningkatan produksi tanaman pangan lokal yang telah dilaksanakan untuk mendukung ketahanan pangan provinsi NTT, yaitu program statistik pertanian tanaman pangan lokal, program intensifikasi penanaman jagung, program peta dan data kekeringan, program perbanyakan benih lokal, program intesifikasi penanam pisang unggulan lokal, program penanaman singkong unggulan lokal.

Berbagai program ini belum memberikan hasil yang signifikan bagi perbaikan kondisi peningkatan produksi pertanian dan pendapatan petani sehingga ketahanan pangan penduduk provinsi NTT sangat rapuh terbukti daerah ini senantiasa mengalami rawan pangan, busung lapar, gagal panen pada berbagai kabupaten.

Menurut Kepala Bidang Ketersediaan dan Kerawanan Pangan, Badan Ketahanan Pangan dan Penyuluhan Provinsi NTT(Pos Kupang, 28 Juli 2010), bahwa sampai dengan bulan Juni 2010 jumlah warga NTT yang mengalami ancaman kerawanan pangan mencapai 1.236.479 jiwa yang tersebar pada 1.481 desa. Jumlah desa yang ada di NTT sebanyak 2.836, dengan demikian terdapat 52,22 persen desa di NTT mengalami ancaman rawan pangan.

\section{Implementasi Peningkatan Produksi Tanaman Lokal}

a. Dimensi Organisasi

Dimensi organisasi dalam implementasi kebijakan peningkatan produksi tanaman lokal belum dilaksanakan secara optimal. Sejumlah indikator dipakai untuk mengukurnya adalah pembentukan panitia kerja, kewenangan yang cukup bagi implementor kebijakan, kejelasan standar kebijakan dan prosedur dalam implementasi, dan ada tidaknya overlapping tugas-tugas unit kerja yang terlibat dalam implementasi kebijakan. Berdasarkan dimensi organisasi memperjelas bahwa organisasi pelaksana dari suatu kebijakan publik mempunyai peranan untuk keberhasilan pelaksanaan program. Seperti halnya dengan organisasi pelaksana kebijakan peningkatan produksi tanaman pangan lokal di NTT. Pembentukan panitia merupakan upaya untuk membentuk struktur organisasi pelaksana yang akan menangani programprogram dan kegiatan dalam peningkatan produksi tanaman pangan lokal.

Berdasarkan struktur tersebut maka akan tergambar mengenai kewenangan dan tanggung jawab dari personil yang mengisi struktur tersebut, memperjelas standar prosedur pekerjaan yang dilakukan dalam pencapaian tujuan program, sehingga dengan sendirinya akan kelihatan apakah ada overlapping pelaksanaan tugas ketika personil melaksanakan tugas dan tanggung jawabnya.

Menurut pendapat E.Wight Bakke yang dikutip oleh Henry (1980:62), organisasi adalah suatu kesatuan yang dikoordinasikan secara sadar, dengan sebuah batasan yang relatif dapat diidentifikasi, bekerja atas dasar yang relatif terus menerus untuk mencapai tujuan bersama.

Berdasarkan hasil temuan-temuan dalam artikel-artikel yang dimuat pada pada Pos 
Kupang dan Kompas, diketahui bebarapa hal yang menghambat dimensi organisasi dari implementasi kebijakan peningkatan produksi tanaman pangan lokal di NTT yaitu: 1. Panitia kerja yang dibentuk sering bersifat Top-Down artinya panitia kerja yang dibentuk tersebut sering kurang melibatkan organisasi pelaksana pada level operasional misalnya tingkat kecamatan dan desa, padahal panitia kerja adalah aparatur yang paling banyak berinteraksi dengan kelompokkelompok masyarakat (kelompok tani) serta paling memahami kondisi sebenarnya dari permasalahan yang dihadapi dalam peningkatan produksi tanaman pangan lokal.

2. Dari segi kewenangan panitia kerja yang sudah terbentuk, panitia tersebut tidak bisa bekerja secara efektif karena hambatan deskripsi tugas unit yang ada belum dinyatakan secara eksplisit. Surat keputusan pembentukan panitia kerja hanya dinyatakan secara umum, tanpa lampiran deskripsi tugas masing masing unit yang terlibat.

3. Mengingat mekanisme dan prosedur kerja belum dibuat maka berimplikasi pada tugas operasional dari aparatur. Organisasi tersebut tidak memiliki SOP (standard Operational procedure) sebagai pedoman kerja sehingga kegiatan-kegiatan lapangan seringkali berdasarkan pada keinginan/selera masing-masing personil yang menangani bidang tugasnya. 4. Koordinasi antar unit yang terlibat dalam pelaksanaan peningkatan produksi tanaman pangan lokal tidak berjalan sebagaimana mestinya. Hal ini disebabkan oleh forum komunikasi tidak berjalan baik. Rapat-rapat tidak berlangsung secara periodik, melainkan hanya bersifat insidental jika ada permintaan laporan dari kepala dinas tanaman pangan selaku penanggung jawab kegiatan peningkatan produksi tanaman pangan

lokal

\section{b. Dimensi Interpretasi}

Hasil studi pustaka menunjukkan interpretasi dengan indikator: komitmen mengenai keberhasilan program peningkatan produksi tanaman pangan lokal, kejelasan program, konsistensi pelaksanaan program, dan penyusunan prioritas program peningkatan produksi tanaman pangan lokal. Hasil penelitian dimensi interpretasi ini memperjelas bahwa interpretasi suatu kebijakan berperanan terhadap implementasi kebijakan publik. Artinya, semakin baik interpretasi yang dilakukan oleh aparatur maka akan semakin efektif pula peningkatan produksi tanaman pangan lokal di provinsi NTT.

Kebutuhan utama bagi efektivitas pelaksanaan kebijakan adalah bahwa implementor harus mengetahui secara jelas apa yang seharusnya dilakukan. Jika kebijakan ingin dilaksanakan dengan tepat, arahan dan petunjuk pelaksanaan tidak hanya diterima tetapi juga harus jelas. Ketidakjelasan mengenai apa yang seharusnya dilakukan implementor menyebabkan kebingungan baginya, sehingga pada akhirnya mereka bertindak berbeda dengan pandangan dari atasannya.

Sejalan dengan pandangan ini Jones (1994: 323), menegaskan bahwa: "Interpretasi terhadap kebijakan publik sangat penting bagi implementor oleh karena merekamenganggap bahwa hukum, perundang-undangan, keputusankeputusan, pedoman serta perintah bersifat definitif (tetap), padahal seringkali tidak demikian. Oleh sebab itu, perhatian yang besar harus diberikan kepada cara yang digunakan oleh para pelaksana dalam menafsirkan tanggung jawab mereka, kepada siapa para pelaksana itu berorientasi? Siapa yang memiliki otoritas? Semua pertanyaan ini membawa kepada eksplorasi sejumlah perluasan yang dianggap dimiliki oleh para pelaksana".

\section{c. Dimensi Aplikasi}

Hasil penelitian menunjukkan aplikasi dengan indikator: ketersediaan personil, ketersediaan anggaran, ketersediaan sarana dan prasaraana, pengidentifikasian penggunaan lahan, dan penilaian atas keberhasilan program. Hasil penelitian dimensi aplikasi ini memberi kejelasan bahwa aplikasi sangat berperanan penting dalam implementasi kebijakan. Artinya, semakin baik aplikasi, 
maka akan semakin efektif peningkatan produksi tanaman pangan lokal. Pentingnya aplikasi dari suatu kebijakan publik sejalan dengan pendapat Anderson (1976: 72) yang menyatakan: "Application of the policy by the governments administrative machinery to problem. Applying the government policy to the problem." Implementasi sebagai aplikasi dari kebijakan dalam mesin administrasi pemerintahan untuk menangani problematika.

Menurut Mazmanian dan Sabatier (1983: 8), aplikasi sangat menentukan keberhasilan pelaksanaan kebijakan, karena dengan aplikasi maka kebijakan ditransformasi secara terus menerus dengan tindakan pelaksanaan yang mengubah sumber daya dan sasaran-sasaran sehingga sesuai dengan tujuan yang ditetapkan semula. Dengan aplikasi maka implementasi terdiri dari perubahan sasaran sesuai dengan ketersediaan sumber daya atau mobilisasi sumber daya baru untuk mencapai tujuan awal dari kebijakan.

Sehubungan dengan aplikasi ini, aparatur dituntut untuk menerapkan kebijakan dengan cara menyediakan barang dan jasa. Dengan adanya pengerahan segala sumber daya diharapkan akan muncul respon dari kelompok sasaran, apakah menerima atau menolak implementasi dan hasil kebijakan tersebut.

Oleh karena itu, implementasi kebijakan mempunyai output yang dapat memberikan outcomes kepada kelompok sasaran, sebagaimana Dunn (1994: 338) menyatakan, "The goods, service, or resources received by target group and beneficiaries. "Segi aplikasi dalam proses implementasi kebijakan juga diperlukan dalam rangka mengeliminasi berbagai hambatan pelaksanaan kegiatan.

Berdasarkan hasil penelitian berbagai laporan dan artikel pada Pos Kupang dan Kompas mengenai implementasi kebijakan peningkatan produksi tanaman pangan lokal, diketahui bebarapa hal yang menghambat aplikai kebijakan yaitu:

a. Anggaran yang dialokasikan untuk peningkatan produksi tanaman pangan lokal sangat sedikit. Alokasi anggaran kecil juga berkaitan dengan usulan program untuk peningkatan tanaman pangan lokal juga relatif sedikit. Program yang diusulkan yakni program statistik pertanian tanaman pangan lokal, program intensifikasi penanaman jagung, program peta dan data kekeringan, program perbanyakan benih lokal, program intesifikasi penanaman pisang unggulan lokal, program penanaman singkong unggulan lokal (Pos Kupang, 12 Mei 2010).

b. Data dasar (date base) yang menyangkut luas areal lahan, potensi areal, jumlah produksi tanaman pangan lokal belum memiliki data yang pasti. Masingmasing instansi yang terkait memiliki data yang berbeda.

\section{Implementasi Strategi Pembangunan Ketahanan Pangan Lokal di Nusa Tenggara Timur, khususnya di SMK-PP Negeri Kupang.}

Dalam melaksanakan pembangunan ketahanan pangan di wilayah Nusa Tenggara Timur, penulis yang berprofesi sebagai pendidik berusaha membuat terobosan agar supaya ketahanan pangan di wilayah NTT bisa bertambah melalui aspek pendidikan dengan cara yang diadopsi dari strategi pembelajaran Dick \& Carey yaitu:

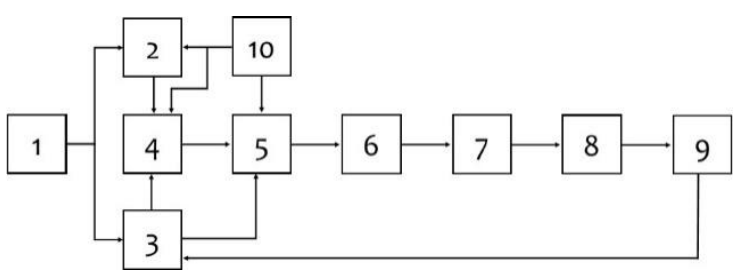

Gambar 2. Alur langkah Dick \& Carey untuk paket pembelajaran .

Keterangan:

1. Menilai kebutuhan untuk mengidentifikasi tujuan umum pembelajaran (Asessing needs to identify instructional goal)

2. Melakukan analisis tujuan umum pembelajaran (Conducting a Goal Instructional Analysis)

3. Menganalisis pebelajar dan lingkungan (Analyze learner and context)

4. Menulis tujuan khusus (Writing performance Objectives) 
5. Mengembangkan Instrumen Penilaian ( Developing Assesment Instructional)

6. Mengembangkan strategi pembelajaran ( Developing and instructional strategy)

7. Mengembangkan materi pembelajaran ( Developing Instructional materials)

8. Merancang dan melakukan evaluasi formatif ( Designing and conducting formative evaluation)

9. Merevisi Pembelajaran( Revise Instruction)

Dari langkah langkah diatas penulis modifikasi ke dalam strategi pembangunan ketahanan pangan di wilayah NTT, khususnya di wilayah SMK-PP Negeri Kupang.Adapun hasil modifikasi tersebut adalah sebagai berikut:

a. Menilai kebutuhan untuk mengidentifikasi tujuan umum pembangunan ketahanan pangan di SMK-PP Negeri Kupang, yaitu sebagai berikut:a). Masih banyaknya pola pikir dan budaya konsumtif dari warga SMKPP Negeri Kupang, b). Masih banyaknya lahan kosong/ pekarangan yang belum di berdayakan oleh warga SMK-PP Negeri Kupang, c). Sumber Daya Manusia di sekitar SMK-PP Negeri Kupang yang malas, d). Tingkat pendidikan warga disekitar wilayah sekolah yang rendah.

b. Melakukan analisis tujuan umum, setelah kita menilai kebutuhan dasar yang ada di wilayah sekitar sekolah, maka langkah selanjutnya adalah menentukan tujuan umum pembangunan ketahanan pangan di wilayah sekitar sekolah, yaitu sebagai berikut:a). Menumbuhkan pola pikir Produktif pada masyarakat sekitar sekolah, b).Pemberdayaan dan pemanfaatan lahan kosong di wilayah sekitar sekolah, c). Menumbuhkan semangat berkarya dan bertanam di wilayah sekitar sekolah.d). Meningkatkan kualitas dan ketrampilan bagi masyarakat sekitar SMK-PP Negeri Kupang

c. Menganalisis masyarakat dan lingkungan, latar belakang pekerjaan masyarakat sekitar SMK-PP Negeri Kupang, sebagian besar adalah petani/peternak sebesar $80 \%$, PNS sebesar $15 \%$, wiraswasta sebesar $5 \%$ ,Sebagian besar pola pertanian di sekitar sekolah adalah pola pertanian lahan kering dan peternakan sistem lepas/ liar tanpa di kandang. Hal ini dapat mendorong bagi masyarakat untuk memiliki minat dan mengembangkan ketahanan pangan di bidang pertanian dan peternakan.

d. Menulis tujuan khusus, setelah kita menganalisis tujuan umum dan masyarakat dan lingkungan sekolah, kita menentukan tujuan khusus pembangunan ketahanan pangan, yaitu sebagai berikut:

\section{Tujuan Umum Pembangunan Ketahanan Pangan di wilayah SMK-PP Negeri Kupang}

Menumbuhkan pola pikir produktif pada masyarakat sekitar sekolah

Pemberdayaan dan pemanfaatan lahan kosong di wilayah sekitar sekolah

Menumbuhkan semangat berkarya dan bertanam di wilayah sekitar sekolah.

\section{Tujuan Khusus Pembangunan Ketahanan Pangan di wilayah SMK-PP Negeri Kupang}

- Dapat mengolah hasil pertanian ke bentuk yang bernilai ekonomis lebih tinggi.

- Dapat mencukupi kebutuhan dan ketahanan pangan di wilayahnya dan NTT secara umum.

- Dapat meningkatkan kesejahteraan keluarga dan wilayah sekitarnya.

- Dapat mengurangi tingkat kemiskinan dan kelaparan di sekitar lingkungannya. 


\begin{tabular}{|c|c|}
\hline $\begin{array}{c}\text { Tujuan Umum Pembangunan } \\
\text { Ketahanan Pangan di wilayah SMK-PP } \\
\text { Negeri Kupang }\end{array}$ & $\begin{array}{c}\text { Tujuan Khusus Pembangunan } \\
\text { Ketahanan Pangan di wilayah SMK-PP } \\
\text { Negeri Kupang }\end{array}$ \\
\hline $\begin{array}{l}\text { Meningkatkan kualitas dan ketrampilan ba } \\
\text { masyarakat sekitar SMK-PP Negeri Kupa }\end{array}$ & $\begin{array}{l}\text { - Dapat memupuk semangat kerjasama dan } \\
\text { gotongroyong bagi keluarga dan } \\
\text { lingkungannya. } \\
\text { - Dapat menciptakan ketahanan pangan di } \\
\text { wilayah lingkungannnya. } \\
\text { - Dapat menciptakan generasi petani yang } \\
\text { cerdas, adaptif serta berfikir kedepan. } \\
\text { - Dapat mengatasi permasalahan pangan di } \\
\text { segala kondisi dan bisa menciptakan } \\
\text { produk-produk pangan yang inovatif. }\end{array}$ \\
\hline
\end{tabular}

e. Mengembangkan Instrumen Penilaian, dari rumusan tujuan pembelajaran khusus dapat dikembangkan instrumen penelitian Instrumen penelitian disusun secara langsung untuk mengukur kemampuan dan ketrampilan awal masyarakat sekitar SMK-PP Negeri Kupang yang digambarkan dalam tujuan melalui empat acuan pokok yaitu:

i. Tes perilaku awal atau entry behaviour test. Tes ini di harapkan dalam kegiatan penyuluhan dengan tujuan untuk mengukur keterampilan yang dimiliki masyarakat pada tingkat permulaan penyuluhan.

ii. b). Tes pendahuluan / Pre test adalah tes acuan yang berguna untuk menentukan perolehan hasil akhir.

iii. c). Tes sambil jalan atau tes integrasi adalah tes acuan yang di lakukan ketika berlangsungnya penyuluhan.

iv. d). Post test adalah tes acuan yang mencakup seluruh tujuan penyuluhan yang mencerminkan hasil belajar yang dilakukan masyarakat petani.

f. Mengembangkan strategi pembelajaran, pengembangan strategi pembangunan ketahanan pangan melalui pendidikan/ penyuluhan mencakup lima komponen yaitu: 1) kegiatan pra pendidikan/penyuluhan, 2) penyajian informasi, 3) partisipasi partisipan, 4) penilaian, dan 5) kegiatan lanjutan (follow through).Kegiatan pra pendidikan/penyuluhan meliputi: 1) menarik perhatian dan memotivasi belajar peserta penyuluhan, 2) menjelaskan tujuan dan menginformasikan apa yang harus mereka lakukan dan pelajari, 3) memastikan pengetahuan prasyarat sebelum memulai penyuluhan. Penyajian informasi meliputi informasi konsep yang perlu diberikan kepada peserta penyuluhan dilengkapi contohcontoh dan demonstrasi. Partisipasi peserta penyuluhan dilakukan dengan cara memberi kesempatan pada peserta penyuluhan untuk mempraktekkan dan kalau bisa memberikan feed back. Penilaian dilakukan terhadap tes perilaku masukan, pre test, dan post test dengan mengacu pada acuan patokan. Kegiatan tindak lanjut yaitu mereview keseluruhan dari strategi dan aplikasi strategi pembelajaran ini tertuang dalam alur bahan ajar yang dikembangkan.

Setelah melakukan keenam langkah tersebut kita adakan kegiatan tindak lanjut dari pendidikan/penyuluhan dengan membantu masyarakat sekitar yang masih terdapat masalah/ kesulitan dalam pengembangan ketahanan pangan di lingkup keluarganya, tingkat RT, baru ke tingkat desa/ kelurahan. Dengan adanya pemenuhan kebutuhan ketahanan pangan keluarga dan tingkat masyarakat, 
diharapkan dapat menumbuh kembangkan/sebagai pioner menuju pembangunan ketahanan pangan di tingkat Nusa Tenggara Timur.

\section{SIMPULAN}

Untuk menciptakan ketahanan pangan di tingkat nasional harus di mulai dengan pemenuhan kebutuhan pangan tingkat lokal, pemenuhan ketahanan pangan tingkat lokal harus di perkuat pembangunan ketahanan di bidang keluarga yang merupakan sebagai kunci dari suksesnya program ketahanan pangan tingkat nasional. Daerah ini paling sering mengalami rawan pangan dengan berbagai implikasinya seperti busung lapar, kekurangan gizi bagi balita, dan kelangkaan pangan. Dilihat dari luas panen dan potensi tanaman pangan lokal, yang tergarap baru sekitar 45 persen, mengidikasikan bahwa jika potensi tersebut dioptimalkan maka kemungkinan dapat memberikan kontribusi yang lebih besar terhadap produksi, yang tentu saja ketahanan pangan di daerah ini dapat tercapai.

Kebijakan yang diambil oleh pemerintah daerah dalam mengatasi persoalan ketahanan pangan tentu saja tidak akan memberikan faedah berarti jika kebijakan tersebut tidak diimplementasikan dengan baik. Kebijakan hanya sekedar menjadi dokumen yang telah menguras pemikiran para pakar dan praktisi, juga sumber daya menjadi terbuang tanpa mencapai hasil yang diharapkan.

\section{REKOMENDASI}

Pemerintah sebagai pemangku kebijakan dan lembaga pendorong serta penyemangat bagi tercapainya kemakmuran, kesejahteraan, dan keamanan, seharusnya lebih memotivasi dan mendorong masyarakatnya untuk berkarya, bekerja dan melakukan kerja nyata tanpa harus mengobral janji -janji, seperti semboyan pemerintah sekarang "Kerja Nyata". Dan pembangunan ketahanan pangan nasional akan terwujud jika pemerintah pusat, daerah dan desa bersinergi dengan masyarakat secara intensif berkelanjutan mendorong terciptanya swasembada pangan(ketahanan pangan) di tengah perubahan iklim yang cukup ekstrim ini.

\section{DAFTAR PUSTAKA}

Anderson, James E. 1976. Public Policy Making, Chicago: Holt, Renehart and Winston.

Badan Ketahanan Pangan dan Penyuluhan Provinsi NTT. 2009. Laporan Tahunan.

Badan Ketahanan Pangan dan Penyuluhan Provinsi NTT.2015. Seri AnalisisPembangunan Wilayah Provinsi NTT Tahun 2015.

Budja, Paulus. 2010. Tantangan Perubahan Sistem Ketahanan Pangan Masa Depan, Pos Kupang, 06 Mei 2010.

Dick, W., Carey, L., \& Carey, J.O. 2001. The Systematic Desain Of Instruction (5 thed). USA:Addison Wesley Educational Publishers Inc.

Dick, W., Carey, L., \& Carey, J.O. 2009. The Systematic Desain Of Instruction (7 th ed). United State of Amerika: Pearson Education Inc.

Dunn, William N. 1981. An Introduction to Public Policy Analysis,Englewood Cliff, Prentice-Hall.

Dreze, Jean and Amartya Sen. 1989. Hunger and Public Action, Oxford: Clarendon Press.

Edward III, George. 1980. Implementing Public Policy, Washinton DC: Congresional Quartely Press.

Hadar, Ivan A. 2008. Anjloknya Ketahanan Pangan, Kompas 05 September 2008.

Henry, Nicholas. 1980. Public Administration and Public Affairs, Englewood-Cliffs, Prentice-Hall. Jones, Charles O. 1984. An 
Introduction to the Study of Public Policy, Third Edition, California: Wadsworth, Inc.

Kompas Tanggal 19 Maret 2005.

Lassa, Jonatan. 2009. Diskursus Kelaparan dan Ketahanan Pangan Indonesia 1958-2008: Studi Kasus Nusa Tenggara Timur, dalam 50 Tahun Ziarah Pangan Nusa Tenggara Timur Jonatan Lassa, Dion DB Putra, Tony Kleden (Editor), Kupang: PT Timor Media Grafika.

Mazmanian, D. A \& Paul A. Sabatier.1983. Implementation and Public Policy, London: Scott, $\quad$ Foresmanand Company.

Maxwell, Daniel G. 1996. Measuring food insecurity: the Frequency and Severity of Coping Strategies, Food Policy, 21 (2):291-304.

Pakpahan, Agus dan Effendi Pasandaran. 1990. Keamanan Pangan: Tantangan dan Peluangnya, Dalam Prisma No. 2 Tahun XIX, Jakarta: LP3ES. Program
Pembangunan Daerah NTT, Tahun 2004-2008.

Pos Kupang 11 Maret 2009.

Pos Kupang, 12 Mei 2010.

Pos Kupang 28 Juli 2010.

Suryana, Achmad. 2008. Sustainable Food Security Development in Indonesia: Policies and Its Implementation, Makalah yang diketengahkan pada High-Level Regional Policy Dialogue, Bali: Un-Escap and Government of Indonesia.

Timmer, C Peter. 2005. Food Security and Economic Growth: an Asian Perspective, dalam Asian Pacific Economic Literature, 19 (1): 2-3.

Van Meter, D. S and C.E. Van Horn. 1974. The Policy Implementation Process: A Conceptual Framework Administration and Society 6. 